\title{
ТЕМПОРАЛЬНА ОРГАНІЗАЦІЯ МОВЛЕННЯ ВАЛЛІЙЦІВ
}

\section{TEMPORAL ORGANIZATION OF THE WELSH ENGLISH SPEAKERS}

\author{
Карпова Д.М., \\ orcid.org/0000-0001-6760-2573 \\ кандидат філологічних наук, \\ дочент кафедри англійської мови № 2 \\ Начіонального університету «Одеська морська академія»
}

Робота розкриває аспекти синтагматичного членування, темпу та паузації в мовленні носіїв валлійського варіанту англійської мови з урахуванням гендерного фактору. роботі розглядається і уточнюється термін Welsh English, описано статус валлійського варіанту англійської мови, визначено територіальні ареали його поширення. Англійська мова є засобом спілкування більшої частини мешканців Уельсу, що дозволяє погодитись із терміном Welsh English, однак використання цього терміну не завжди слушне, оскільки він не відображає всього різноманіття діалектів англійської мови, які існують на території Уельсу. У виконаному фонетичному дослідженні встановлено, що мовлення мешканців Уельсу варіює під впливом гендерного і регіонального факторів.

Синтагматичне членування валлійського мовлення відрізняється подрібненістю, наявністю заповнених сполучників, слів-філерів, фральстартів. Вплив гендерного фрактора варіативності синтагматичного членування виявляється в тому, що кількість односинтагмених фраз у чоловічому мовленні вдвічі більша, ніж у жіночому, проте кількість семисинтагмених фраз удвічі переважає в жіночому мовленні: Трисинтагмені фррази представлено приблизно в однаковій кількості як у чоловічому, так і в жіночому мовленні.

Автор зазначає, що двосинтагмені фррази домінують у чоловічому мовленні, а чотирисинтагмені - у жіночому. У регіональних групах простежується збільшення кількості односинтагмених фраз із Півночі на Південь. Найменшу кількість заповнених і мішаних пауз зафіксовано в мовленні інформантів із Півночі, найбільшу - з Центру. Спостерігається тенденція зменшення кількості заповнених пауз із Півночі на Південь. Найбільша кількість мішаних пауз маркує мовлення мешканців Центру, а найменша - мешканців Півночі.

Отримані результати сприятимуть детальнішому аналізу соціолінгвальної варіативності будь-якої вимови і мовленнєвої поведінки представників різних соціальних груп.

Ключові слова: синтагматичне членування, валлійський варіант англійської мови, Уельс, паузи заповнені, змішані.

The present article reveals main aspects of syntagmatic devision, tempo and pausation in the speech of the representatives of Welsh English has been described; the territorial areas of Welsh English spreading have been defined. On the one hand, the English language is the means of communication for the greater part of Wales' inhabitants and this fact allows to agree with the term Welsh English, and on the other hand, this term is not always rightly used, as doesn't reflect the whole variety of English dialects, which exist on the territory of Wales. The conducted phonetic investigation allows to state that the speech the Welsh varies under the influence of gender and regional factors.

Syntagmatic devision of the Welsh English speakers differs by its fractional character, presence of filled conjuctions, word-fillers and falsestarts. The influence of gender factor of syntagmatic devision variation is revealed in the fact that the number of one sense group utterances in the male speech is twice more than in female speech. Three sense-group utterances are presented approximately equally in male and female speech.

It has been established that two sense group utterances dominate in male speech and four sense group utterances in female speech. In regional groups rising amount of one sense group utterances is observed on the verge from the North to the South. The fewest number of filled and mixed pauses is fixed in the speech of the informants from the North and the largest from the Center. The tendency of lowing down the amount of filled pauses is observed from the North to the South.

The results of the investigation will contribute to more detailed analysis of sociolingual variation of any type of pronunciation and speech behavior of various social groups' representatives.

Key words: syntagmatic devision, Welsh English, Wales, pauses, filled, mixed.

Постановка проблеми. Функціональна парадигма сучасної англійської мови, що сформувалась історично, нині становить складну, ієрархічно організовану систему різних форм ii існування, містить літературну мову, різновиди побутоворозмовної мови та територіальні діалекти.

Як мова-посередник англійська в сучасному світі відіграє роль мови міжкультурної взаємодії. У зв'язку з появою великої кількості так званих нових варіантів англійської мови всередині Великої Британії (в Ірландії,
Шотландії, Уельсі) посилюється процес нативізації мови, тобто процес зміни англійської мови під впливом місцевих мов. При цьому відбувається не лише формування, а й зміна форм і структур так званого «стандартного» варіанту англійської мови.

Аналіз останніх досліджень i публікацій. Дослідження просодії діалектного мовлення неодноразово привертало увагу вітчизняних і зарубіжних дослідників (О.Р. Валігура, В.С. Григораш, О.Д. Петренко, О.Б. Рубчак, Т.І. Шевченко). 
Функціонування валлійського варіанту англійської мови висвітлено в розробках зарубіжних лінгвістів, зокрема О. Бродович, Р. Волтерса, П. Тенча, А. Томаса, де стверджується, що валлійський варіант англійської мови, який домінує на території Уельсу, є результатом взаємодії двох мов - валлійської, що зберегла свою ідентичність, та англійської. У сучасній ситуації двомовності спостерігається взаємопроникнення елементів двох фонологічних систем.

Постановка завдання. Метою дослідження $\epsilon$ вивчення темпу мовлення досліджуваних валлійців. Основним завданням запропонованого аналізу мовлення представників валлійського варіанту англійської мови є визначення особливостей синтагматичного членування, яке тісно пов'язано з темпом мовлення, а також паузації.

Виклад основного матеріалу. Дослідники валлійського варіанту англійської мови по-різному підходять до питання про стандартний варіант англійської мови в Уельсі. Платт (J. Platt) і його співавтори [7] у своїй класифікації англійських діалектів не відносять валлійський варіант англійської мови (а також шотландський i корнуелльський варіанти) до поняття «нові англійські» (англ. New Englishes), припускаючи, що в Уельсі використовується стандартний варіант. П. Традгіл (Р. Trudgill) [10] також говорить про використання стандартної англійської мови в Уельсі, однак він вказує на присутність соціальної варіативності в регіоні, що відбивається в акценті мешканців Уельсу. А. Томас (A. Thomas) пише про регіонально-модифікований варіант Received Pronunciation [9].

Питання про статус варіанту англійської мови, яку використовують мешканці Уельсу, про його позицію в цій ієрархії, а також коректний термін для позначення цього варіанту залишається відкритим. В англомовній літературі існує кілька точок зору щодо цієї проблеми.

Найпоширенішим у літературі терміном $\epsilon$ Welsh English, який зустрічається в енциклопедичних статтях, присвячених валлійському варіанту англійської мови, а також широко використовується в англійських ЗМІ. Однак Д. Перрі, який одним із перших почав вивчати англійську мову в Уельсі, при проведенні масштабного дослідження діалектів Уельсу віддав перевагу терміну Anglo-Welsh. Термін Welsh English часто викликає негативну реакцію з боку валлійців, оскільки факт існування такого поняття трактується як своєрідна ідеологічна капітуляція перед Англією. Р. П'єнхаулрік вважає, що англійська мова 3 певними модифікаціями є засобом спілкування для більшої частини населення Уельсу, що дає змогу говорити про існування самостійного варіанту англійської мови - Welsh English.

$\mathrm{У}$ цій роботі автор оперуватиме розгорнутим терміном валлійський варіант англійської мови, користуючись ним для опису сучасної мовної ситуації в регіоні. Водночас спостереження Р. П'єнхаулріка щодо наявності більше ніж одного варіанта англійської мови в Уельсі також підтвердилося під час цього дослідження мовлення носіїв валлійського варіанту англійської мови, які мешкають у різних регіонах Уельсу і належать до різних гендерних груп.

Як перша мова валлійська $є$ найпоширенішою переважно на сільських півночі і заході Уельсу, передусім у Гуінеті, Денбіширі, Айл-Оф-Англсі, Кармартенширі, Північному Пембрукширі, Кередігіоні й частинах західного Гламоргана, людей, які гарно говорять валлійською, можна зустріти по всьому Уельсу. При цьому вона майже не використовується у великих містах на півдні, де мешканці визначають себе як валлійці, але не говорять валлійською.

Нині урбаністичний південь із такими великими містами як Кардіфф, Ньюпорт і Свонсі контрастує 3 сільськогосподарською північчю. Однак відмінності в економічному устрої не обов'язково відбиваються на рівні життя населення. Так, найбіднішою частиною Уельсу вважаються саме південні рівнини, які постраждали від припинення вуглевидобутку й закриття шахт. Що стосується відмінностей у національній самосвідомості, то вони досить істотні, при цьому роль мови і особливості діалекту характеризуються самими валлійцями.

Зазначений географічний поділ відбивається і на особливостях англійської мови в різних частинах країни. М.В. Федотова зазначає, що на півдні англійська мова перебуває підвпливом м. Бристоля й регіону Уест-Кантрі; у центрі має деякі загальні характеристики $з$ англійським районом Мідлендс; на півночі багато в чому схожа з варіантом, який використовується в Мерсісайд [5].

Основним завданням фонетичного аналізу було визначення особливостей синтагматичного членування досліджуваних уривків мовлення, характер паузації, а також темпу вимовляння, який для зручності було поділено на швидкий, помірний і повільний. Також було підраховано кількість складів на секунду з урахуванням паузації.

Основною одиницею дослідження було обрано тональну групу (або синтагму), тобто відносно закінчений за змістом відрізок мовленнєвого ланцюга, межі якого визначаються тільки просодич- 
ними засобами. Синтагма - фонетична єдність, яка виражає єдине змістовне ціле в процесі мовлення-думки, що складається як із однієї ритмічної групи, так і з декількох [6, с. 86].

Результати проведеного аудиторського аналізу демонструють, що мовленню мешканців Уельса притаманна дрібність синтагматичного членування, що пояснюється більшою кількістю синтагм у фразах. Синтагми зазвичай короткі, заповнені сполучниками, словами-філерами, повторюваними словами, самовиправленнями (або «фальстартами») і звуками некомунікативного характеру (іноді затягуванням звуків), що дає підстави стверджувати про наявність великої кількості заповнених пауз і змішаних пауз хезитації в мовленні мешканців Уельсу.

Варіативність синтагматичного членування фраз у мовленні мешканців Уельсу з урахуванням їх гендерної належності наведена в таблиці 1.

Результати проведеного синтагматичного членування фраз аудиторами-філологами показують, що найбільш рекурентними в мовленні мешканців Уельсу є чотирисинтагмені і трисинтагмені фрази. За частотою вживання за ними йдуть двосинтагмені та п'ятисинтагмені фрази.

Розглядаючи синтагматичне членування фраз з урахуванням гендерної специфіки, автор зазначає, що кількість односинтагмених фраз у чоловічому мовленні вдвічі більша, ніж у жіночому, у той час як кількість семисинтагмених фраз удвічі переважає в жіночому мовленні. Трисинтагмені фрази представлені приблизно в однаковому відсотковому відношенні як у чоловічому, так і в жіночому мовленні. Двосинтагмені фрази домінують у чоловічому мовленні, а чотирисинтагмені - у жіночому.

Автор наводить варіативність синтагматичного членування мовлення в кореляції з регіональною належністю мовців (рис. 1):

Існує залежність синтагматичного членування фраз від регіональної належності інформантів. Слід зазначити таку тенденцію: спостерігається

Таблиця 1

Синтагматичне членування мовлення. Гендерна варіативність

\begin{tabular}{|c|c|c|c|c|c|c|c|}
\hline \multirow{2}{*}{$\begin{array}{c}\text { Гендерна } \\
\text { належність }\end{array}$} & \multicolumn{7}{|c|}{ Синтагматичне членування мовлення (\%) } \\
\hline & $\begin{array}{c}\text { одна } \\
\text { синтагма }\end{array}$ & $\begin{array}{c}\text { дві } \\
\text { синтагми }\end{array}$ & $\begin{array}{c}\text { три } \\
\text { синтагми }\end{array}$ & $\begin{array}{c}\text { чотири } \\
\text { синтагми }\end{array}$ & $\begin{array}{c}\text { п'ять } \\
\text { синтагм }\end{array}$ & $\begin{array}{c}\text { шість } \\
\text { синтагм }\end{array}$ & $\begin{array}{c}\text { сім } \\
\text { синтагм }\end{array}$ \\
\hline Чоловіки & 9 & 19 & 28 & 23 & 7 & 9 & 3 \\
\hline Жінки & 7 & 12 & 27 & 34 & 9 & 8 & 5 \\
\hline Середнє у групі & 8 & 15,5 & 27,5 & 28,5 & 8 & 8,5 & 4 \\
\hline
\end{tabular}

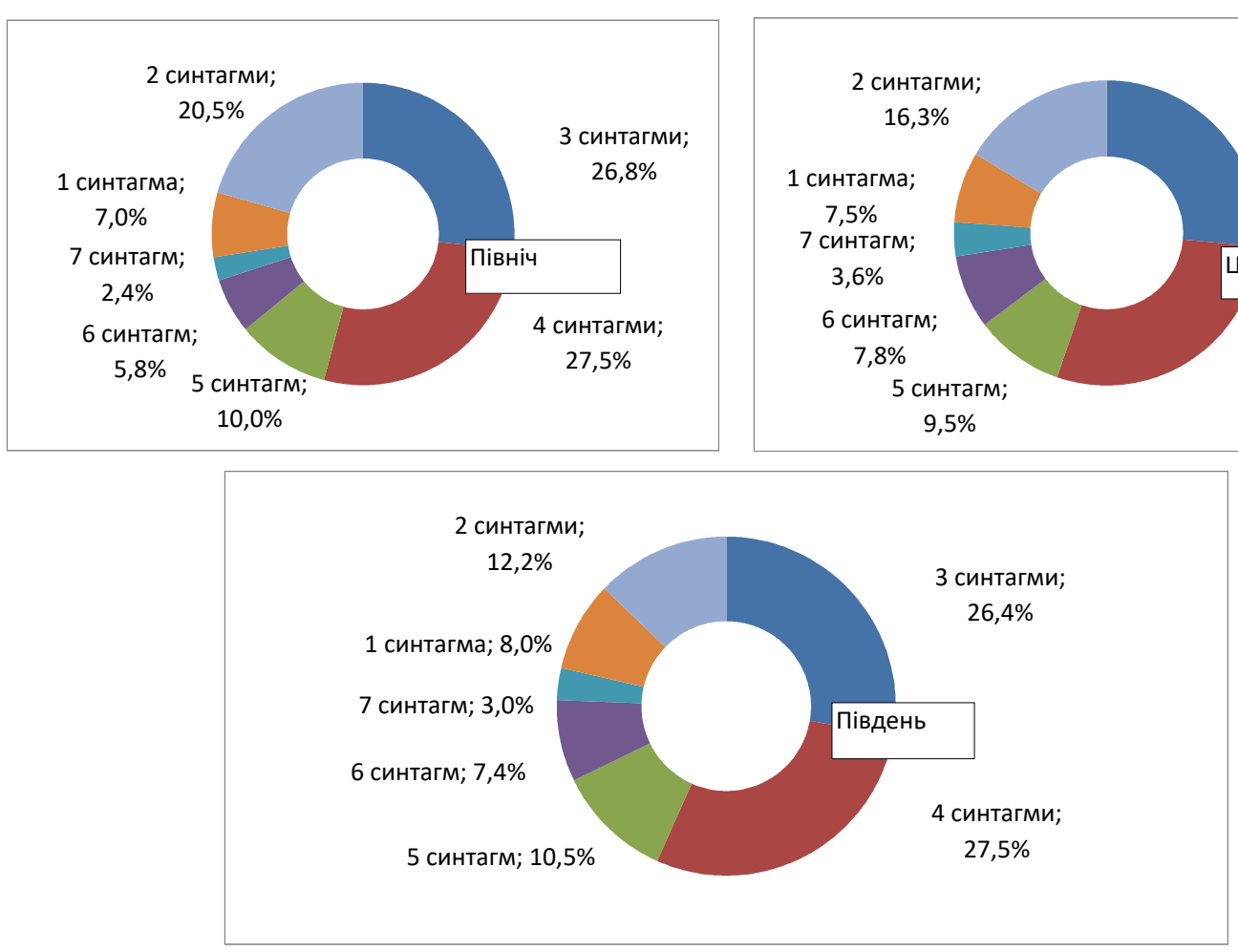

Рис. 1. Синтагматичне членування мовлення. Регіональна варіативність 
збільшення кількості односинтагмених фраз при просуванні з Півночі на Південь. Найбільша кількість двосинтагмених фраз маркує мовлення мешканців Півночі. Частотність використання трисинтагмених фраз приблизно однакова в мовленні представників усіх регіонів. Найбільша кількість чотирисинтагмених фраз і найменша кількість п'ятисинтагмених фраз маркує мовлення мешканців Центру. Найменшу кількість шестисинтагмених фраз зафіксовано в мовленні мешканців Півночі, а найбільшу - в Центрі. Аналогічна тенденція спостерігається і за частотністю вживання в мовленні семисинтагмених фраз.

Автор наводить кілька уривків із мовлення валлійців, які демонструють різноманітність синтагматичного членування мовлення (рис. 2). Обраний фрагмент мовлення чоловіка-археолога з Північного Уельсу характеризується дрібним синтагматичним членуванням: перша фраза складається 3 восьми синтагм, друга - 3 п'яти. У мовленні превалюють однонаголошені спадні i рівні типи шкал, а також висхідні та спадновисхідні термінальні тони, які реалізуються у вузькому діапазоні.
I was 'born in, 1964|, in, wrexham, | in 'north wales, |, um, | where I, grew up, |'went to school, | till I was about, 18. || Then I 'went to 'university in birmingham, | in the 'middle of england, | which is, has a 'very 'distinct accent| which I didn't really get that 'much, of. $\|$

Наступним етапом фонетичного аналізу темпоральних характеристик було визначення темпу мовлення мешканців Уельсу, а також вивчення специфіки вживання заповнених і незаповнених пауз.

Стосовно мовленнєвої специфіки аудитори зазначили, що мовлення мешканців Уельсу характеризується помірним темпом. Відмінною рисою можна назвати уповільнення на останньому ядерному складі і його «затягування». Спостерігалася i певна уповільненість чоловічого мовлення порівняно $з$ жіночим.

Заповнені й мішані паузи у валлійському мовленні $є$ досить частотними і складають приблизно чверть від загальної кількості всіх пауз. Кількість абсолютно заповнених пауз домінує над кількістю мішаних пауз.

Враховуючи співвідношення заповнених i незаповнених пауз у мовленні інформантів

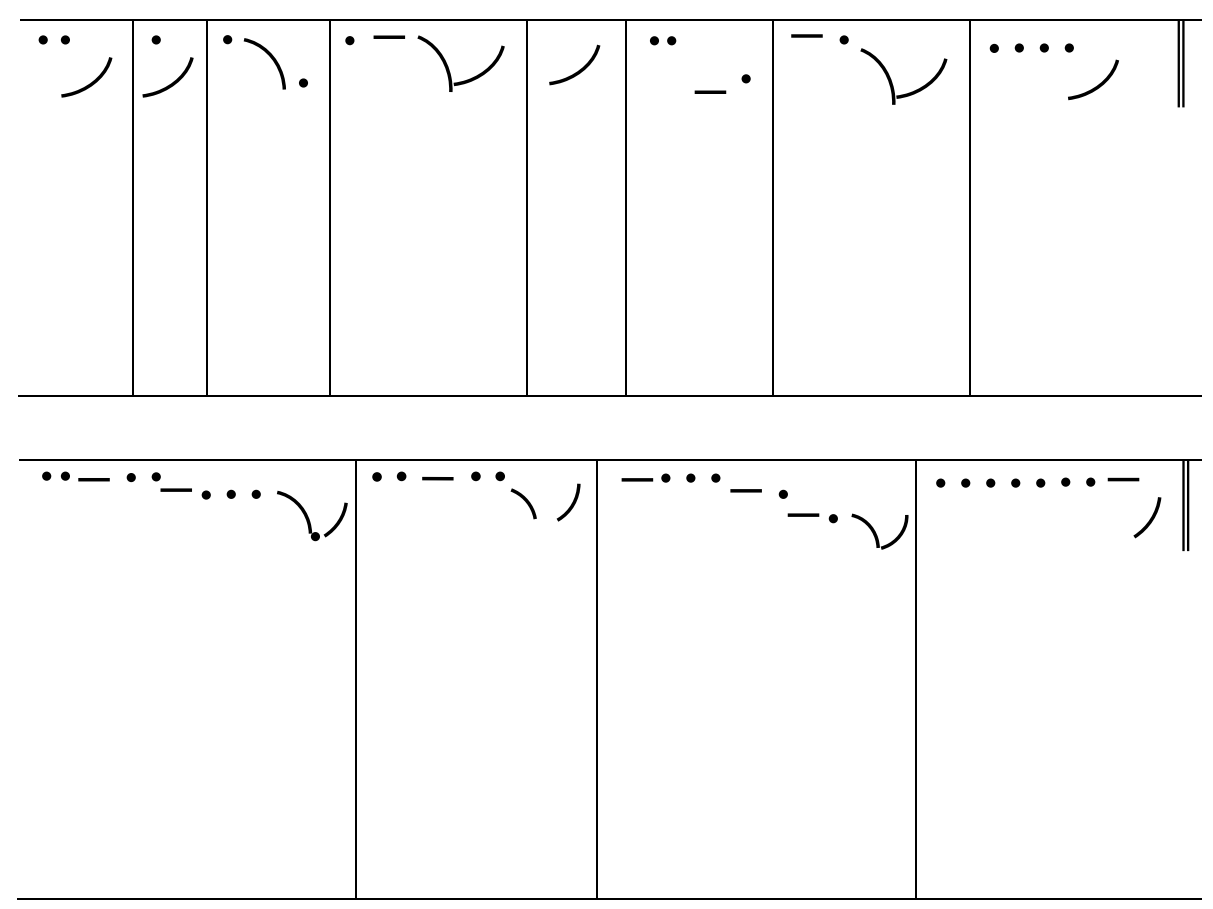

Рис. 2. Інтонограма наведеної вище фрази

Таблиця 2

Співвідношення заповнених і незаповнених пауз. Гендерна варіативність (\%)

\begin{tabular}{|l|c|c|c|}
\hline \multicolumn{1}{|c|}{ Гендерна належність } & Заповнені паузи (\%) & Незаповнені паузи (\%) & Мішані паузи (\%) \\
\hline Чоловіки & 24,0 & 62,0 & 14,0 \\
\hline Жінки & 18,0 & 83,0 & 9,0 \\
\hline Середнє у групі & 21,0 & 72,5 & 11,5 \\
\hline
\end{tabular}




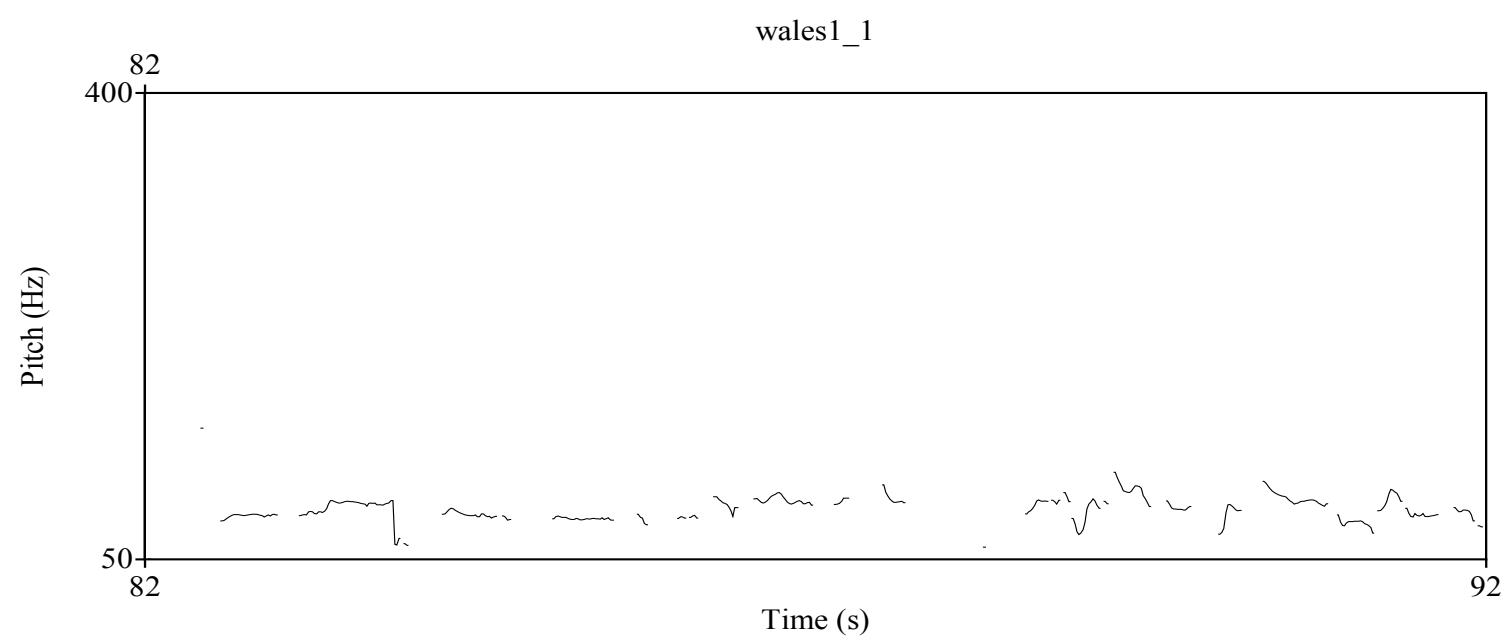

$\rightarrow$ Um, $\bullet$ and then, $\mid$ when $\bullet$ I, I'd finished there, | I went back to, | and lived up in the countryside in the far north of England, in Northumberland, |

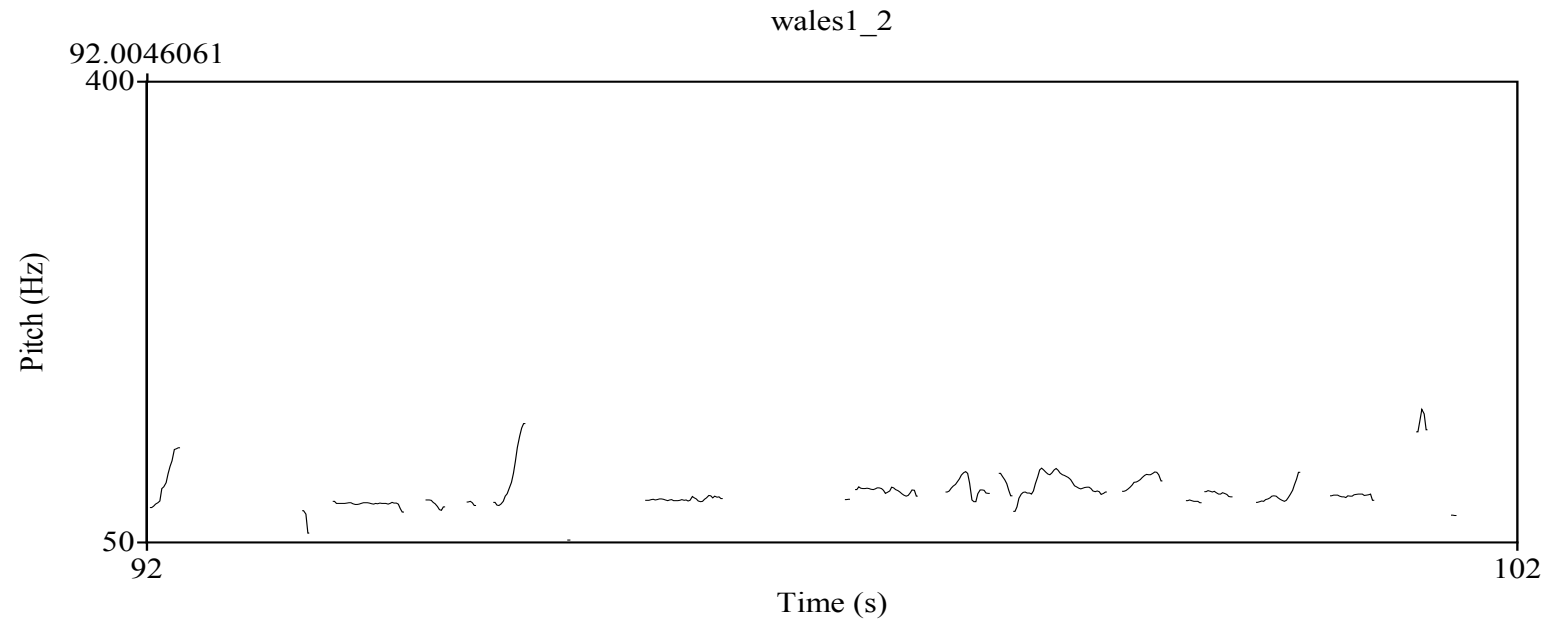

um, $\bullet$ by the seaside. $\|$ And, $\bullet$ then after that, a couple of more years there,| I moved to York in Yorkshire, |

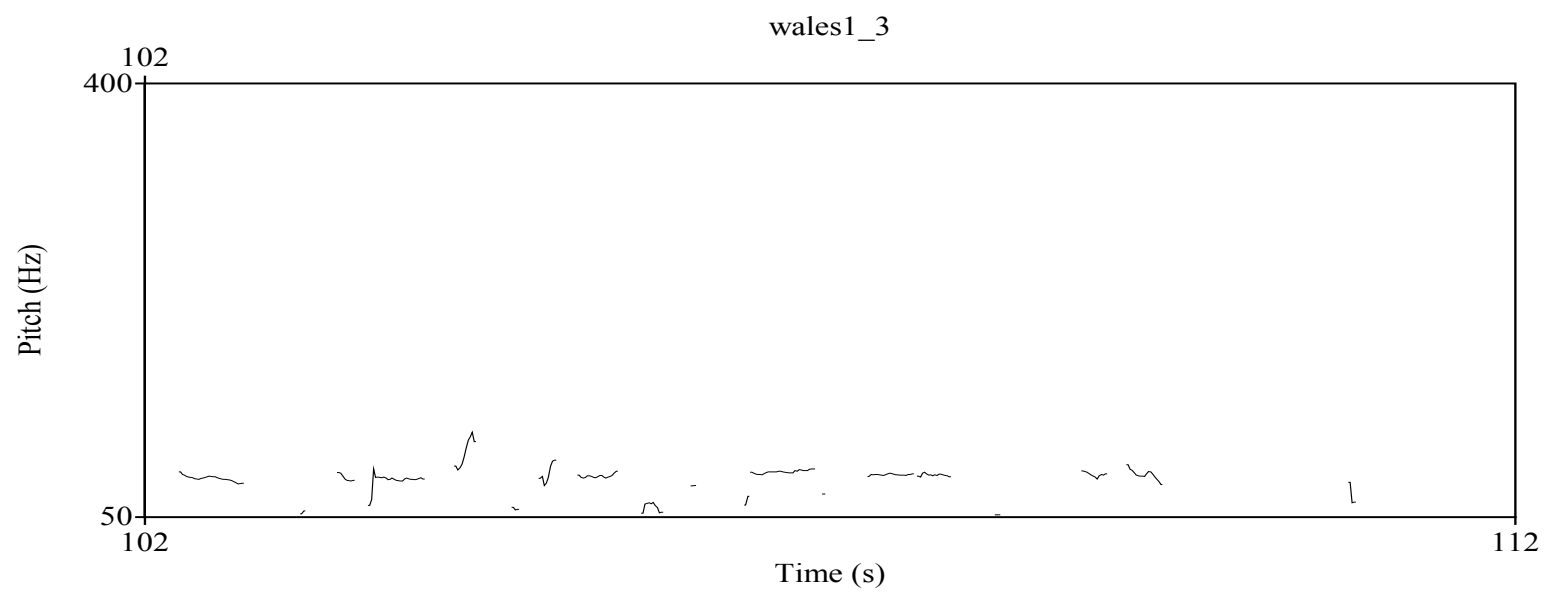

to er (заповнена пауза + тиша) • to go to the university, | to go back to the university, | um (зanoвнена пауза + тиша), • and $\bullet$ I'm still there. \|

Рис. 3. Паузальная насиченість мовлення мешканця Півночі 


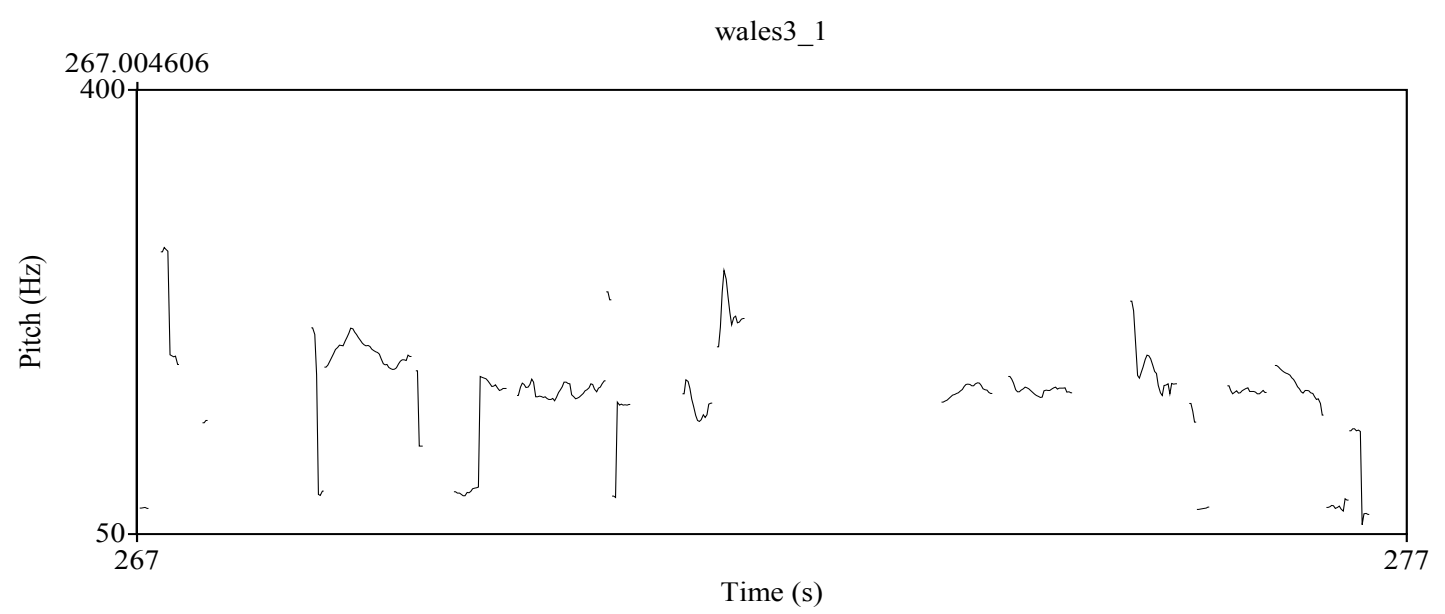

Then I went to work in a ladies' club, | as, erm, • waitress in a dining room ||

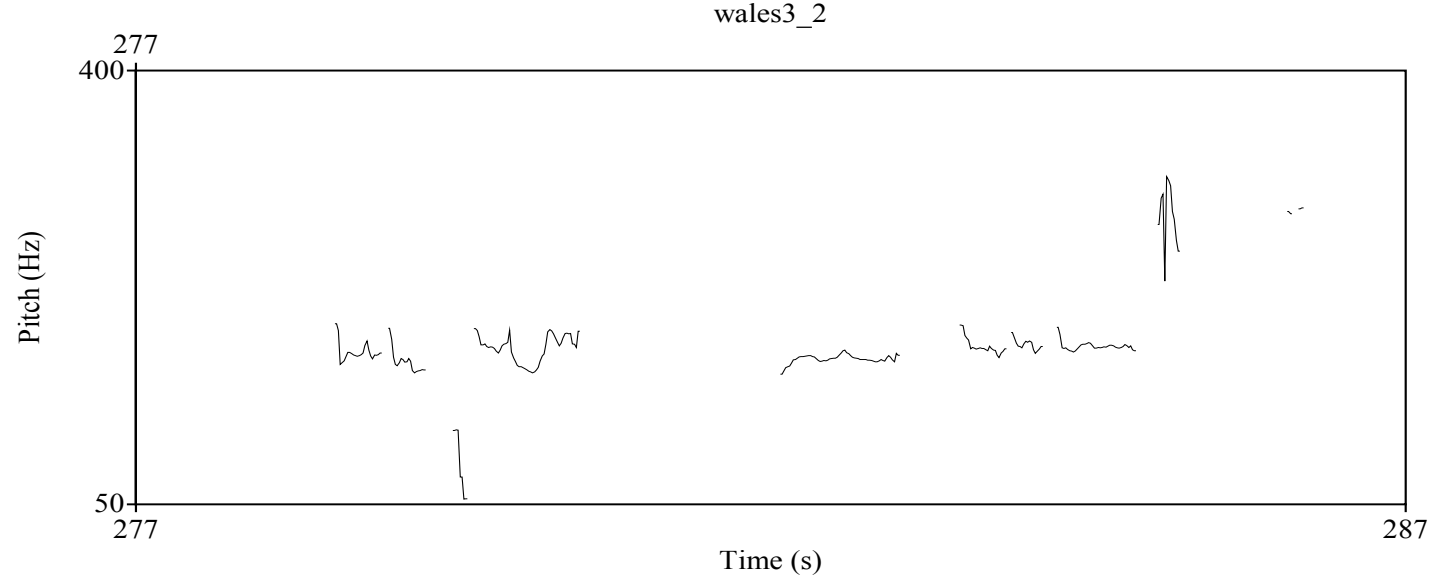

And then from, $\bullet$ uh, $\bullet$ then on, $\mid I$, uh, $\bullet$ went into, uh, $\bullet$

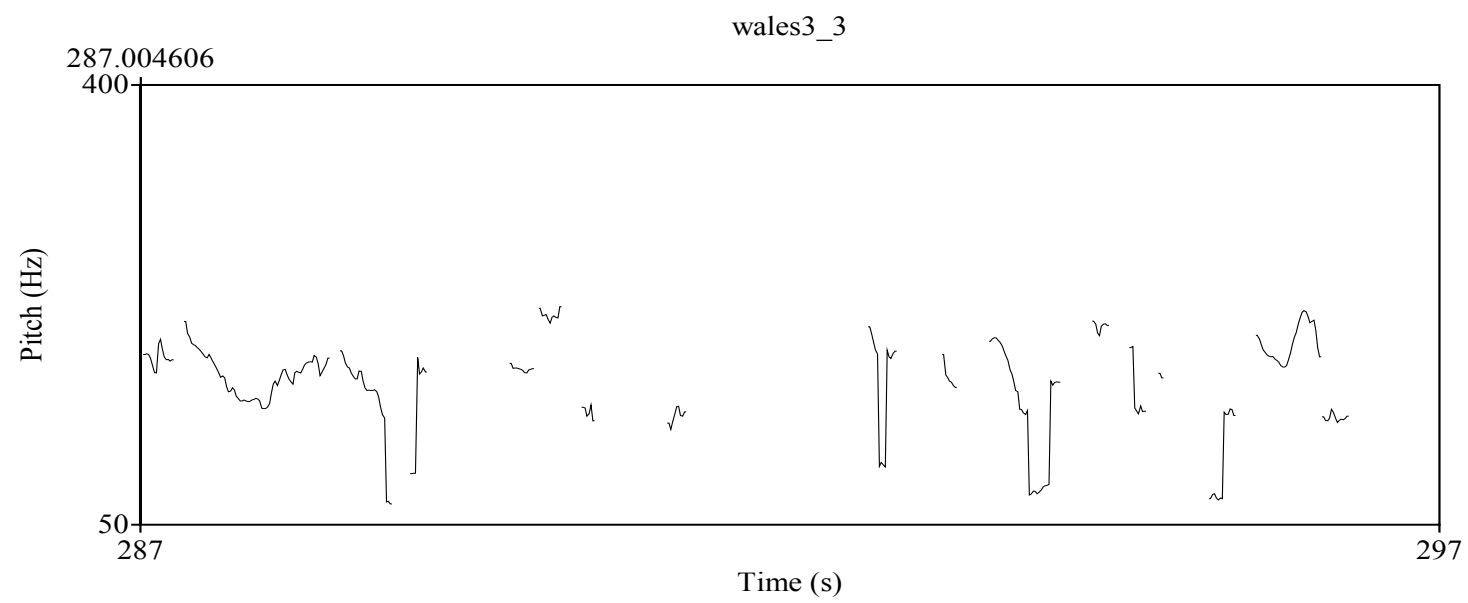

with a friend of mine went to Redden, | to a biscuit factory, | Peek Freans biscuit factory in Redden $\|$

Рис. 4. Паузальна насиченість мовлення мешканки Півдня 


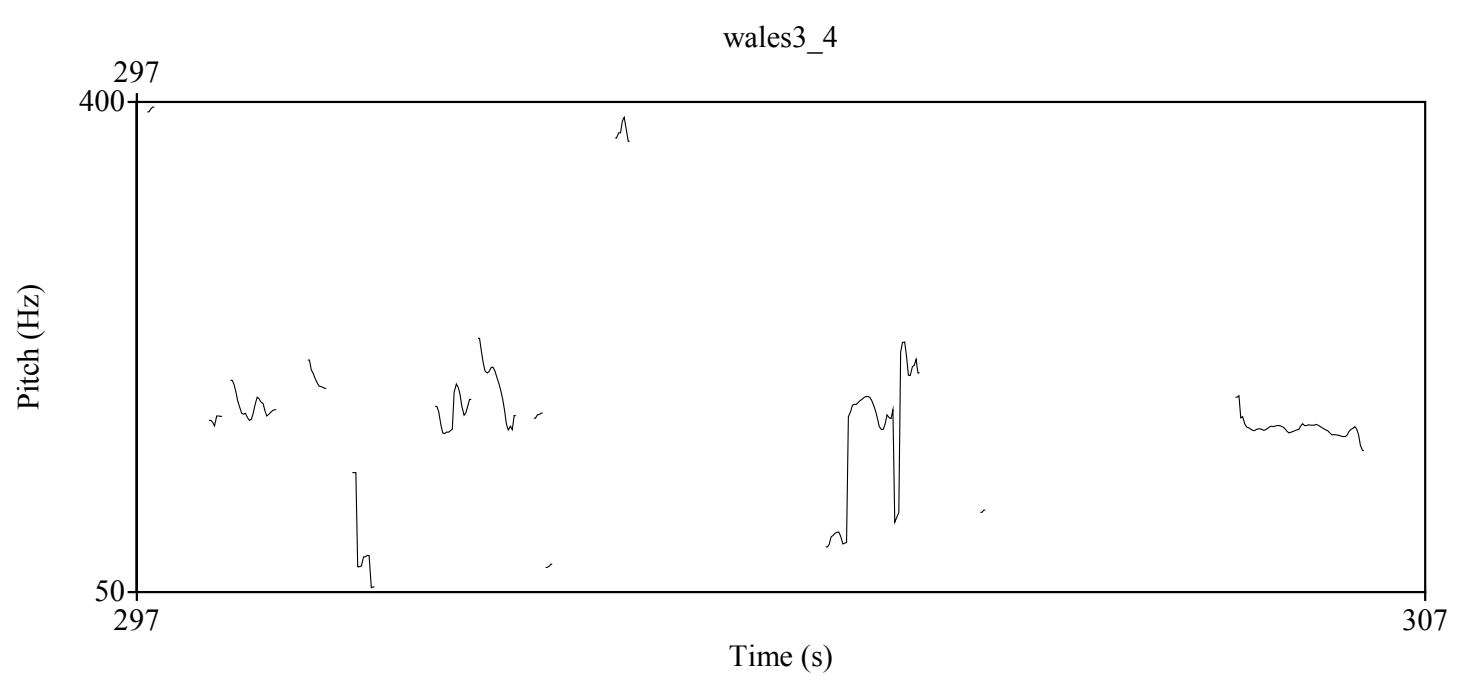

Packing biscuits for the forces. $\|$ And then $\bullet$ I, er, $\bullet$

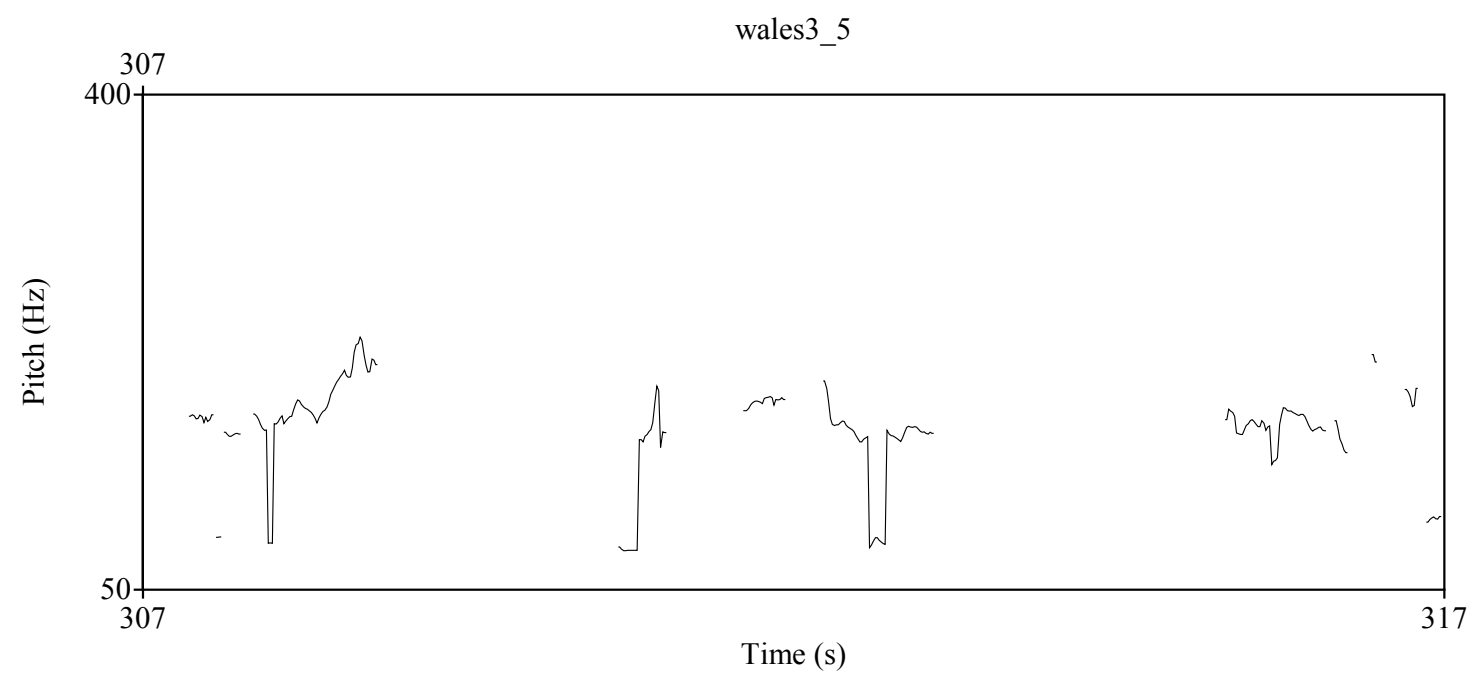

went back to London \|. And ah, • went to, erm, er, • where was it, | Clacton, Cl, wales3_online-audio-converter_com_

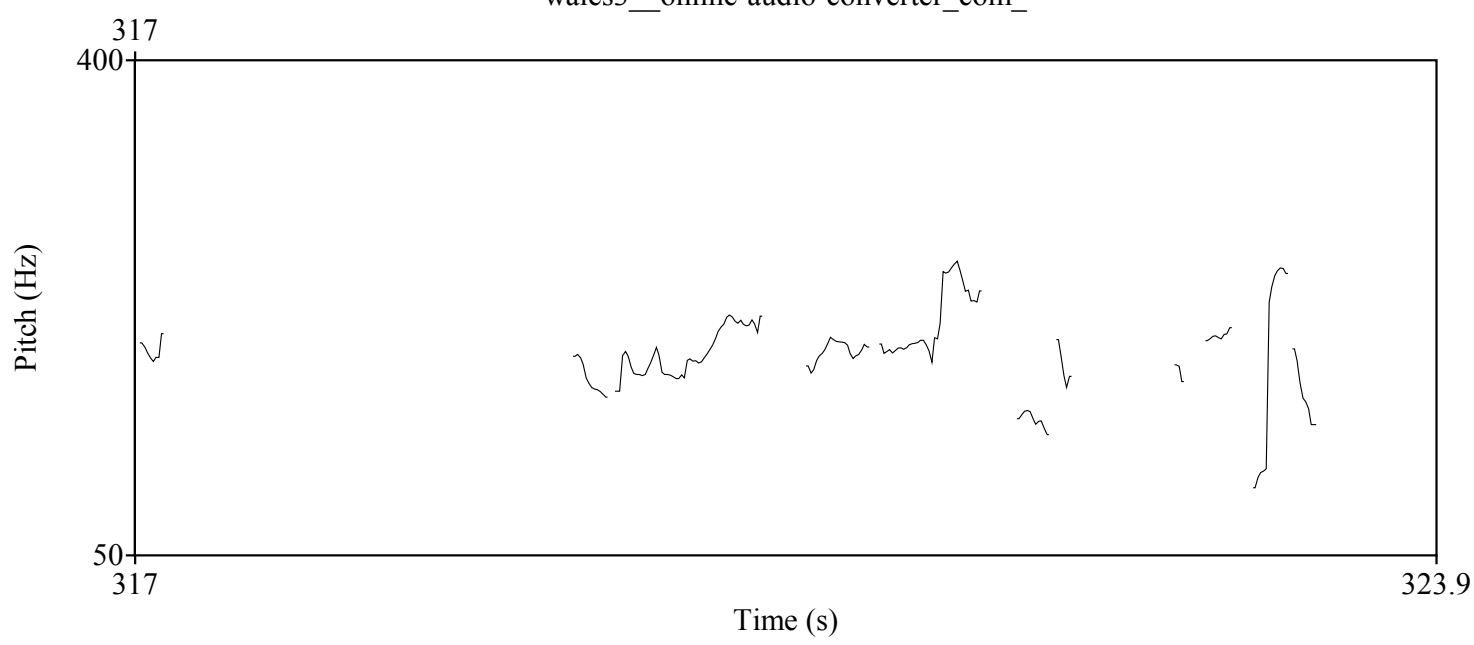

for a holiday, | and met my husband ||. And got married. \|

Продовження рис. 4. Паузальна насиченість мовлення мешканки Півдня 
3 Уельсу, автор зазначає, що в чоловічому мовленні заповнені й мішані паузи в сумі превалюють порівняно 3 жіночим мовленням. Кількість заповнених пауз є більшою порівняно 3 кількістю мішаних пауз як у чоловічому, так і в жіночому мовленні.

Автор наводить приклад паузального членування і насиченості мовлення чоловіка-археолога, мешканця Півночі (рис. 3).

Досліджуваний монологічний уривок характеризується дрібним синтагматичним членуванням: обидві фрази складаються 3 п'яти синтагм. У мовленні опитаного чоловіка представлені всі види пауз (заповнені, незаповнені та мішані). Серед хезитаційних наповнювачів зустрічаються звуки некомунікативного характеру (um...), сполучники (and...), а також повтори (I...).

Інформант робить дві мішані паузи хезитації, які виконують комунікативну фатичну функцію, а саме допомагають здійснювати контроль і корекцію мовлення, а також підібрати необхідні лексичні та граматичні конструкції. Всі заповнені паузи інтонаційно оформлено рівними термінальними тонами. Наявність великої кількості заповнених і мішаних пауз пов'язана не тільки 3 комунікативною ситуацією спілкування та регіональною належністю, але й з віковими особливостями мовців.

У наведеному вище фрагменті жінка-пенсіонерка 3 Півдня розповідає про свою роботу в молоді роки й зустріч із майбутнім чоловіком (рис. 4).

У наведеному фрагменті наявні як односинтагмені і двосинтагмені, так і чотирисинтагмені фрази, а також дещо уповільнений темп мовлення й наявність заповнених і мішаних пауз. Серед «філерів» присутні як звуки некомунікативного характеру, так і повтори початкових звуків слова.

Висновки. У виконаному фонетичному дослідженні встановлено, що мовлення мешканців Уельсу варіює під впливом гендерного і регіонального факторів.

Синтагматичне членування валлійського мовлення вирізняється подрібненістю, наявністю заповнених сполучників, слів-філерів, фальстартів. Вплив гендерного фактора варіативності синтагматичного членування виявляється в тому, що кількість односинтагмених фраз у чоловічому мовленні вдвічі більша, ніж у жіночому, проте кількість семисинтагмених фраз удвічі переважає в жіночому мовленні- Трисинтагмені фрази представлено приблизно в однаковій кількості як у чоловічому, так і в жіночому мовленні. Двосинтагмені фрази домінують у чоловічому мовленні, а чотирисинтагмені - у жіночому. В регіональних групах простежується збільшення кількості односинтагмених фраз із Півночі на Південь. Найменшу кількість заповнених і мішаних пауз зафіксовано в мовленні інформантів із Півночі, а найбільшу - з Центру. Спостерігається тенденція зменшення кількості заповнених пауз із Півночі на Південь. Найбільша кількість мішаних пауз маркує мовлення мешканців Центру, а найменша - мешканців Півночі.

Отримані результати сприятимуть детальнішому аналізу соціолінгвальної варіативності будь-якої вимови і мовленнєвої поведінки представників різних соціальних груп.

\section{СПИСОК ВИКОРИСТАНИХ ДЖЕРЕЛ:}

1. Бродович О.И. Диалектная вариативность английского языка: аспекты теории. Л. : ЛГУ, 1988. 193 с.

2. Григораш В.С. Соціолінгвістичні особливості йоркширського діалекту (інструментально-фонетичне дослідження усного мовлення). Автореф. дис. ... канд. фрілол. наук: 10.02 .04 - германські мови. Одеса, 2014. $18 \mathrm{c}$.

3. Петренко А.Д. Социолингвистическая вариативность национального языка как целостной структуры. Севастополь, 2009. $182 \mathrm{c.}$

4. Рубчак О.Б. Просодична організація англомовних інтерв'ю (експериментально-фонетичне дослідження). Автореф. дис. канд. фрілол. наук: 10.02.04 - германські мови. Київ, 2015. 20 с.

5. Федотова М.В. Мелодическая структура восходяще-нисходящего тона как маркер валлийского акцента в английском языке. Вестник Московского государственного лингвистического университета. Серия «Социофонетика звучащей речи». М., 2011. Вып. 1 (607). С. 233-244.

6. Щерба Л.В. О понятии смешения языков. Избранные работы по языкознанию и фонетике. Т. 1. Л. : Учпедгиз, 1958. $186 \mathrm{c.}$

7. Platt J., Weber H., Ho M. L. New Englishes. London : Routledge and Kegan Paul, 1984. 225 p.

8. Tench P. The Pronunciation of English in Abercrave'. Coupland N. English in Wales. Multilingual Matters, Clevendon, 1990. P. 131-141.

9. Thomas A.R. Welsh English. Language in the British Isles. Cambridge : Cambridge University Press, 1984. P. 178-194.

10. Trudgill P. International English: A Guide to Varieties of Standard English. London : Arnold, 1985. 130 p. 